\title{
Listening Strategies Employed by Non-English Department Students
}

\author{
Rohfin Andria Gestanti \\ upin.ndutz@gmail.com \\ Muhammadiyah University of Ponorogo \\ Jl. Budi Utomo No. 10 Ponorogo, Jawa Timur, Indonesia
}

Received: December 19, 2016; Accepted: March 2, 2017; Published: March 3, 2017

\begin{abstract}
Language learning strategy is one of the influential aspects for students' success in learning a language. Basically, language learning strategies are closely related to students taking language-related department. However, students from non-English Department also have the indication of using the strategies since English is one of the subjects taught in the curriculum. Thus this study aims to (1) identify what strategies are used by non-English Department students in Listening class and (2) describes to how the use of strategies influence students listening achievement. This study is a qualitative descriptive study with second-semester students from Governmental Science Department as the research subject. A questionnaire, observation, and documentation are used to collect the data. After analyzing the data, it was found that some strategies are used by non-English department students in their Listening subject, namely memory strategies, cognitive strategies, compensation strategies, metacognitive strategies, affective strategies, and social strategies. Moreover, the students use those strategies in moderate level. Thus, a comparison between the level of strategies use and students' listening scores is made to describe to what extends the use of strategies influence students' achievements.
\end{abstract}

Keywords: listening, language learning strategies, non-English department students

How to cite this paper: Gestanti, R. A. (2017). Listening Strategies Employed by Non-English Department Students. Journal on English as a Foreign Language, 7(1), 35-58. 
In classroom activities, listening is vital because it provides input for the learners. Adequate input at the right level is the basic to start learning process (Richards, 2002, p. 239). Thus, among four language skills, listening is placed and conducted in the first stage of the learning process. It is the natural precursor to speaking, and it is considered that the early stages of language development in one's first language are dependent on listening. That is why in classroom activities, students always do more listening than speaking. In this case, approximately over than half of the time that students spend in learning a foreign language is allocated in doing listening (Nation \& Newton, 2009, p. 37).

Many amounts of time students spend in their classroom learning is done for listening, even though the activities they had done is integrated with other materials. It is due to the natural cognition of listening as one of the receptive skills. Listening activity as a receptive skill allows students to get meaning from the oral communication they see or hear (Harmer, 2001, p. 199). In this perspective, students are required to interpret the implied message of a spoken language. Therefore, there are some considerations of listening requirements that must be done by the students. They are the situation in which the listening takes place, the reason for conducting the listening, the important message that is carried in the listening, and the rationality of the message in listening (Khamdani, 2014, p. 2). These aspects are significant so that the purpose of listening to language learning can be achieved well.

One of the main purposes of listening in language learning is to get the information from the spoken texts. However, since English is treated as a foreign language, many students find it difficult in doing the listening. In some cases, students could not successfully participate in a listening activity because students' negative perception towards listening English texts appears in their learning activities. This condition, further, affects their listening comprehension as well. Moreover, students' negative perception toward listening also prohibits them from achieving deeper listening' goals (Khamdani, 2014, p. 3).

In order to make the students get to use and achieve the planned listening purposes, the teacher is required to actively provide various listening activities. Besides, it can enhance students' listening competencies as long as the teacher considers well what the students need in learning to listen and how they deal with their learning necessity. In other words, the teacher needs to manage students' learning by considering the way students learn listening. Hence, knowing what learning strategies used by students in listening is beneficial.

Learning strategy is beneficial because it plays a significant role in second or foreign language learning. Language learning strategies are one of learning aspects that can help and facilitate students to achieve, recall, retrieve 
and use the information and to increase their self-confidences (Chang, Liu, \& Lee, 2007, p. 236). Learning strategies are one of many variables that determine students' success in learning a new language (Razawi, 2011, p. 179). Learning strategies can determine students' success because the use of it is considered as the particular actions, behaviors, steps or techniques that are used to assist them to deal with the difficulties of language task, and to enhance self-learning (Celce-Murcia, 2001, p. 359). Therefore, the use of learning strategies cannot be separated in available listening activities.

The strategies in listening are worth to be applied in listening activities as a technique to generate a linguistic and content area of information (Khamdani, 2014, p. 9). In fact, however, many students are not aware concerning the use of strategies in listening. This is represented by their acts that still showing difficulties as they perform in listening. The most reasonable cause of the case is that students are only informed what they have to get from the material they listen to, but students are not well informed about how to get it. This is the reason why knowing students' strategies in listening are significant, particularly towards non-English department students. Because these students, in some cases, are expected to have good English ability, even though they have limitation is practice and direct interaction with English field. Broadly speaking, non-English department students encounter bigger difficulties in learning English because they have a shorter time indirectly contacting or using the language. Thus, they are not fully aware of their English learning and how they can obtain the optimal learning result by ensuring their strategies.

In the Muhammadiyah University of Ponorogo, students from all majors and departments are registered in English certification program because it is one of the requirements for graduation. In this program, the listening material is also included. Since this program is conducted in the first year, students have limited knowledge about to perform well in listening. Instead of speculating on the listening matters, exploring students' strategies in learning is more beneficial. Following the problem and the reason that was given, the current study is conducted to investigate about what kind of learning strategies that are used by students in listening English texts and how the strategies in listening affect students' listening achievement.

In term of language teaching, listening refers to an activity that allows students to understand a spoken language. It is the process of receiving what the speaker states, understanding and expressing meaning, reasoning the meaning and giving a response, and lastly generating meaning through participation, imagination, and understanding (Gilakjani A. P. \& Mohammad, 2011, p. 978). Moreover, listening can be treated as the action of attentively hearing activity (Farlex, 2007, p. 2). It requires the activity of paying attention 
and trying to get meaning from what is heard. Listening does not merely hear something out, instead, it requires the scopes of understanding, paying attention, analyzing, evaluating the spoken messages, and acting on what is heard and what is intended (Khamdani, 2014, p. 14). Those are the aspect that should be provided in listening activities. By taking consideration into the definitions, it can be said that listening is an active process in which the students try to understand and interpret the spoken messages comprehensively by making use of various sources and knowledge. It is an active, dynamic, and selective process in order to make a response to what is heard. That is why during a process of communication, listening is considered as a perceptive yet active process.

Listening play an important role in communication, and to avoid misunderstanding during communication, listeners should have the ability in answering speakers' questions. In this case, doing classroom listening is slightly different from doing the real-life listening. However, listening activities that are provided in the classroom are aimed to accommodate the real-life listening outside the classroom (Ghaderpanahi, 2012, p. 150). In order to do so, listening activities should be designed well so that the activities can accommodate students' comprehensions as complete as possible. As the result, students are able to make use all the knowledge and achieve complete competencies in language learning. In term of learning L2, the process of learning can be conducted in a classroom situation (Ghaderpanahi, 2012, p. 150). In this case, at the first phase of learning to listen in L2, teacher's role is still needed in order to help students identify their difficulties as well as help them to overcome it. Therefore, how listening is processed becomes an important thing to be understood by the teacher.

Broadly speaking, there are two processes of listening activities. They are bottom-up listening and top-down listening (Gilakjani A. P. \& Mohammad, 2011, p. 979). The bottom-up listening process allows the students to start learning from the smallest bits of information - words - to the larger parts in order to build phrases, clauses, and so on. Thus, the whole information can be decoded. In the other hand, the top-down listening process allows the students to learn from their background knowledge and experiences that had been stored in their memories. In this process, students use their prior knowledge to link and make sense the information they heard.

Considering those explanations, listening is widely accepted as one of the most important skills that must be taught. Besides, students are also required to totally achieve this skill. Thus, in order the deliver the teaching of listening to be well packaged, some principles in teaching listening should be taken into consideration (Harmer, 2007, pp. 135-136). They are (a) encourage 
students to listen as often and much as possible, (b) help students prepare to listen, (c) provide more than one teaching activity, (d) encourage students to respond to the content of a listening material instead of the language, (e) adjust the listening task with students' stages of comprehension, (f) try to become a good teacher who exploits the listening text to the full. Furthermore, the listening activities should be designed as comprehensive as possible to prepare them to be effective listeners. The provided listening activities should be able to prevent students from making misconception. As the result, listening activities can support students' interpretation of a particular spoken text (Gilakjani A. P. \& Mohammad, 2011, p. 982).

Generally, listening activities are divided into pre-listening, whilst listening, and post-listening activities. Pre-listening activities usually have two primary goals. The first is to help students in activating their prior knowledge, building up their expectations for upcoming information, and the second is to provide the necessary contexts for a specific listening task. Teacher, in this case, can use the listening material in form of conversation of two people who are talking about their daily life. Then, students are required to answer true-or-false questions based on it. This example of a controlled practice activity can be used as a drill activity to comprehend similar materials.

While-listening activities usually have some of the following purposes: to make students focus on the comprehension of understanding the speaker's language and ideas; to make students pay more attention to speaker's organizational patterns, and lastly to encourage students 'critical reactions and personal responses to the speaker's ideas and use of language. An example of this activity is by providing students various tasks of filling in the missing word. This listening activity could be set as pair work activity where student A and student B have the same worksheets. What they should have to do is completing the missing information in their worksheets.

The third is post-listening activities. These activities provide opportunities for teachers to assess and check students' comprehension thoroughly and clarify their understandings of particular tasks. Besides, it also allows the teacher to extend students' comprehensions from literal level to interpretive and critical levels. During these activities, different comprehension questions can be assigned for students to be discussed after listening, and then students are asked to swap information to complete the whole class chart. Correlating what each student has heard is the next thing to do to arrive at the big picture (Gilakjani A. P. \& Mohammad, 2011, p. 982).

After considering the teaching process, the next thing to be considered is the listening assessment. This is significant to know how far the students convey the result. A listening assessment is needed in the classroom activity to 
know to what extend the lesson is learned by students. The assessment particularly becomes an inseparable part of the course. The main purpose of listening assessment is to evaluate students' comprehension that depends on their ability to recognize stress, intonation, and pattern to maintain what is heard (Weir, 1998, p. 51).

Generally, there are two types of listening assessment. They are extensive and intensive listening assessment. The extensive listening assessment covers multiple choice questions and information transfer techniques. The counterpart, intensive listening assessment involves dictation and listening recall (Weir, 1998, p. 51). The data or scores obtained from this evaluation are used to observe the influence of learning strategies to the students' achievement. As for classroom listening activities, an objective test can be conducted to know the students' comprehension in listening.

Getting many benefits in learning English does not mean that students are merely involved in learning without encountering difficulties. Some problems such as the quality of the recording, cultural diversity, accent, unfamiliar vocabularies, and recording speed and duration are some obstacles that are faced by students (Gilakjani \& Sabouri, 2016, p. 127). Besides, students also encounter problems in term of acuity of hearing (physical problem or environmental problem), discrimination and auditory perception, attention and concentration, and comprehension (Rost, 1994, p. 119). Moreover, students find it difficult when it comes to having trouble with sound, having no idea how to understand every word, being not able to understand as fast as possible, getting natural native speech, making repetition of the audio to understand it better, working continuously, and getting tired (Ur, 1996, p. 113).

The explanations are also supported by Underwood (1989) who stated that there are seven potential difficulties faced by students. First, the speed of delivery is beyond students' control. Second, it is not always possible for students to repeat the words. Third, students' limited vocabulary that frequently impedes listening comprehension. Fourth, students may not recognize the signals that are used by the speaker to move from one point to another. Fifth, it can be very challenging for students to concentrate in a foreign language. Sixth, learning habit such as the desire to understand the meaning of every word is also emphasized and involved in the classroom. The last, comprehension problems of contextual knowledge may obstruct students as well (Underwood, 1989, pp. 16-17). These concerns actually, consciously or not, influence students to find some help in learning.

Taking this matter in mind, students try to deal with the difficulties in listening by using any ways they can afford. In this case, students' ways of learning refer to techniques that are used by students to ease their learning. 
Techniques have something in common with strategies. They refer to all plans that are done to achieve the learning goals (Gestanti, 2015, p. 29). Language learning strategies literally refer to the students' actions or techniques that have been planned. Actually, the strategies are applied to help students in succeeding their second or foreign language learning (Oxford, 1990, p. 8). The strategy is the implementation of a set of procedures or tactics to accomplish something, so learning strategy is a sequence of procedures that are implemented to accomplish the goals of learning (Oxford, 2003, p. 2).

Strategies are certain processes or procedures that are employed by students during their learning process. They also can be defined as actions that are done by the students to get the main principles of successful learning. In this case, students use their own considerations in taking the strategies that are effective yet pleasant for them (Brown, 2006; Oxford, 1990). In other words, learning strategies are actions that are actually and consciously chosen by students in order to ease them in learning a new language. The word consciously, in this case, refers to the situation in which students choose the certain strategies based on their preference. Thus, there is a possibility that students may use strategies that are different from their friends. Besides, students have their own considerations in choosing certain strategies that fit their needs. That is why applying language learning strategies is a conscious process since it occurs through the memory, and requires continuance use and application (Zare, 2012, p. 163).

However, learning strategies are sometimes seen as the learning style. Those two terms have a close relationship yet actually distinct to each other (Shi, 2011, p. 20). Styles are terms that relate either to the personality extroversion, self-esteem, anxiety - or to the cognition - brain orientation, tolerance, sensitivity - that are characterized by the consistent of individuality and distinctiveness among students. In the other hand, strategies are particular methods or planned actions that are consciously done in order to overcome the learning problems or to control and manipulate certain information (Brown, 2006, p. 192). Simply, it can be said that learning styles are the things beyond control that are directed by students' individual personality, while learning strategies are the things that can be controlled, learned or taught consciously (Gestanti, 2015, p. 31). Distinguishing learning styles from its counterpart learning strategies - is significant because those terms are used in different corpus area of study (Brown, 2006, p. 192). Learning styles set their corpus in learning behavior area while learning strategies set their corpus in techniques of learning used by students.

Studies concerning the use of learning strategies in the educational setting have become an interesting issue. Many teachers or researchers start 
focusing their concerns on the development of students' learning strategies (Khamdani, 2014; Basir, 2014; Kassem, 2015). This circumstance is seen as the impact of previous influential research that had been done by some experts (Rubin, 1987; Cohen, 1998; O'Malley et al, 1985; Oxford, 1990; Stern, 1992; etc). As the result, many definitions of learning strategies have appeared. Besides, some classifications also come along with the definitions in which the components of listening strategies are included in. In this present study, the framework that is used to know what the students' learning strategies are the model proposed by Oxford (1990). It is used because the current theory had been completed by the standardized measurement system called as SILL (Strategy Inventory for Language Learning) (Oxford, 1990, p. 293). Oxford's classification divides strategies in more detail, comprehensive, and systematic way. It also can be linked to the four language skills.

Broadly speaking, learning strategies are divided into two major classes with six types of strategies. The first class is direct strategies that consist of memory strategies, cognitive strategies, and compensation strategies. The second class is indirect strategies that consist of metacognitive strategies, effective strategies, and social strategies (Oxford, 1990, p. 17).

Memory strategies are strategies that help students to store and retrieve verbal material and allow students to link the concepts of language without involving deep understanding. Memory strategies include: creating linkages (grouping, associating, placing new words into a context), applying images and sound (using imagery, semantic mapping, using keywords, representing sounds in memory), reviewing well (making a review), and employing action (using physical response, using the mechanical technique.

Basically, cognitive strategies are the most familiar strategies because most of the actions of these strategies are typically done by students. Students use cognitive strategies to manipulate or to use the language material directly. Cognitive strategies include: practicing (repeating, formally practicing with sounds, recognizing and using formulas and patterns, practicing naturalistically), receiving and sending messages (getting the idea quickly, using resources for receiving and sending messages), analyzing and reasoning (reasoning deductively, analyzing expressions, analyzing contrastively, translating, transferring), and creating structure for input and output (taking notes, summarizing, highlighting).

Limited knowledge is one of the biggest problems faced by students in comprehending or producing new language. Therefore, students are suggested to compensate or manipulate the language by making up the missing knowledge through guessing, using mime or gesture, getting help or the other 
ways to overcome the situation. Compensation strategies include guessing intelligently (using linguistic clues, using other clues).

Metacognitive strategies are sort of actions that go beyond the cognitive devices to make students available to coordinate their learning. One of the mentioned actions is organizing the learning material. Metacognitive strategies include: centering your learning (overviewing and linking with already known material, paying attention, delaying speech production to focus on listening), arranging and planning the learning (finding out about language learning, organizing, setting goals and objectives, identifying the purpose of language task, planning for a language task, seeking practice opportunity), and evaluating the learning (self-monitoring, self-evaluating).

Affective is related with someone's feeling or attitude toward something. The significance of affective strategies is that it is directly shown in language proficiency in form of someone's feeling during their performance. Therefore, affective strategies are useful ways to overcome problems regarding students' feelings or emotional conditions. Affective strategies include: lowering anxiety (using progressive relaxation, deep breathing, or meditation, using music, using laughter), encouraging yourself (making positive statements, taking risk wisely, rewarding yourself), and taking emotional temperature (listening to your body, using checklist, writing a language learning diary, discussing with someone else).

Social strategies are strategies that help students to understand the target language by coordinating with the person who has different language culture. Learning a language always involve other people since language is one form of social behaviors. That is why communication becomes one of the important aspects of language learning. Besides, language is important in order to maximize the communication. Social strategies include: asking a question (asking for clarification or verification), cooperating with others (cooperating with peers, cooperating with proficient users of the new language), and empathizing with others (developing cultural understanding, becoming aware of others' thoughts and feelings) (Oxford, 2003, pp. 12-13).

Knowing the language strategies in listening is significant for both teacher and student because the further listening activities can be designed as selective and creative as possible. Besides, it also can trigger the less successful students to adapt the use of the strategies so that they can achieve better results. In conducting listening activities, it is expected that students can be more skillful in receiving and perceiving spoken language and also increasing their interest in listening English texts. As the result, students could decide on their own what strategy suit them the most, as the best way they can do to improve their listening skill. 
To determine what strategies are used by students and how the strategies are used, the current study implements the SILL analysis. It is a form of a questionnaire that is provided by a key to understanding the average score got by students in using strategies. It is provided in Table 1.

Table 1. Average Score

\begin{tabular}{ccc}
\hline Frequency Level & Description & $\begin{array}{c}\text { Range of } \\
\text { Score }\end{array}$ \\
\hline \multirow{2}{*}{ High } & Always or almost always used & 4.5 to 5.0 \\
\cline { 2 - 3 } & Usually used & 3.5 to 4.4 \\
\hline Moderate & Sometimes used & 2.5 to 3.4 \\
\hline \multirow{2}{*}{ Low } & Generally not used & 1.5 to 2.4 \\
\cline { 2 - 3 } & Never or almost never used & 1.0 to 1.4 \\
\hline
\end{tabular}

Source: (Oxford, 1990, p. 300)

Table 1 showed the range of scores on how often the students use the learning strategies. High-frequency level means that students almost or at least usually use the learning strategies. The scores are ranging from 3.5 to 5.0. Moderate frequency level means that the students only sometimes use the learning strategies. The scores are ranging from 2.5 to 3.4. Lastly, low-frequency level means that the students rarely or even never use the learning strategies. The scores are ranging from 1.0 to 2.4. Moreover, the result of this average score on each strategy was also used to determine what strategies that are used the most or the least by the students in listening.

In the previous part, it has been stated that students could have some considerations in using certain strategies. The considerations mentioned here are mostly depend on some factors such as gender, age, degree of awareness, stage of learning, task requirements, topic and subject area, teacher expectations, nationality, general learning style, achievement, students' attitude, motivation level and learning purpose, and teacher's techniques (Oxford, 1990; Cabaysa \& Baetiong, 2010). These factors not only affect students in choosing what strategies suit them the most but also it can be considered as students' reasons in using learning strategies. These factors also influence students' concerns whether to use learning strategies or not. Moreover, another study defined that the factors influencing the strategy choice to fall under four general factors (Liang, 2009, pp. 200-201). Those are learner factor (learners' thought, language learning styles, ages, gender, and students' motivation); situational factor (learning setting and task types); academic factor (academic major); and cultural background (nationality and ethnicity). 


\section{METHOD}

This study is a descriptive qualitative study since it aims to find what strategies that are used by students and how they use the strategies. By employing this approach, the investigation on students' learning strategies in listening can be explained briefly. This study was conducted in Muhammadiyah University of Ponorogo from January until August 2016. By using purposive sampling as the sampling technique, 30 second-semester students of Governmental Science Department were chosen as the subject of the research.

Then the techniques that are used in collecting the data are SILL questionnaire and document analysis in form of students' list of listening scores. Besides, observation is also conducted to slightly observe the teachinglearning process. In order to make sure that the data of this research was worthy, data and methodological triangulation were applied as trustworthiness technique since the data are collected using more than one method. Then in analyzing the data, the interactive model was used (Milles \& Huberman, 1984, pp. 21-22). First, the SILL questionnaires are distributed to the students to collect the data. Once they are completed, they are classified based on Oxford's classification. Then the result is contrasted with students' listening achievement (list of score) during the observation to know its significance, and lastly, the result is verified.

\section{FINDINGS}

The findings showed that actually, students apply all six strategies in listening, namely memory, cognitive, compensation, metacognitive, affective, and social strategies. Based on the result of questionnaire analysis, all those strategies are applied in some specific ways and in a different level of frequency. The summary is provided in Table 2.

It revealed that memory strategies are strategies that are applied the most and social strategies are the least strategies that are applied by students, even though all strategies are, overall, applied in moderate level. It means that only sometimes do the students use or apply the strategies, although generally they apply all the reported strategies.

Then documentation of students' listening achievement was contrasted to know the influence of the strategies towards the listening scores. The result is presented in Table 3. 
Table 2. Summary of Strategy Use

\begin{tabular}{|c|c|c|}
\hline Strategies & $\begin{array}{l}\text { Mean Score of } \\
\text { Strategy Use }\end{array}$ & Implemented Strategies \\
\hline Memory & 3.1 & $\begin{array}{c}\text { Using imagery } \\
\text { Using keywords } \\
\text { Reviewing the known material }\end{array}$ \\
\hline Compensation & 3.0 & Making intelligent guessing \\
\hline Metacognitive & 3.0 & $\begin{array}{c}\text { Paying attention } \\
\text { Defining objectives in listening }\end{array}$ \\
\hline Cognitive & 2.9 & $\begin{array}{c}\text { Making repetition } \\
\text { Translate the words } \\
\text { Using pattern or familiar language rules }\end{array}$ \\
\hline Affective & 2.8 & $\begin{array}{l}\text { Lowering anxiety by having deep breathing } \\
\text { or laughter, } \\
\text { Encouraging themselves by making the } \\
\text { positive statement. }\end{array}$ \\
\hline Social & 2.4 & Making clarification and verification \\
\hline
\end{tabular}

The difference in students' listening and strategies scores represented how the students use the listening strategies in their learning. The result showed that students' mean scores in listening are range from 2.5 to 4 . By using a 4-scale scoring system, the actual scores of the listening classroom are represented by $\mathrm{A}$ and $\mathrm{B}$ mark. It means that students actually have good listening achievements. By comparing the average score of strategies use and the scores of listening tasks, it can be inferred that their listening achievement is good enough. Both scores are higher than each average score and both scores are significant and support each other. When the average score of strategies use is as high as the average score of listening, then both matters are influencing each other.

Table 3. Comparison result between score of listening and score of strategies use

\begin{tabular}{cll}
\hline $\begin{array}{c}\text { Number of } \\
\text { students }\end{array}$ & Average score of listening & Average score of strategies use \\
\hline 18 & $3.26-4$ (A mark) & $2.9-3.3$ (Moderate use) \\
\hline 12 & $2.5-3.25$ (B mark) & $2.3-2.8$ (Low to Moderate use) \\
\hline
\end{tabular}

Source: questionnaire and document analysis

\section{DISCUSSION}

From the findings, it was revealed that students of non-English department apply more than one strategy in listening. In this case, all the reported strategies are employed in a different level of average use. It revealed that memory strategies are the strategies that are used the most by the students, and social strategies are the strategies that are used the least. The success of 
listening English text, indeed, can be achieved when students apply more than one strategy. Instead of using only one strategy at hand, combining two or more strategies in the learning process can enhance students' self-learning. Students can be said as successful language learners when they can make and use the combination of strategies (Cabaysa \& Baetiong, 2010, p. 24).

A well-designed listening activity requires a good application of learning strategies and enhances the use of strategies. In other words, it can be said that students who apply strategies comprehensively also have good performances in language learning (Zhang, 2007, p. 75). In addition, students are basically aware of the strategies they use to assist them in their listening tasks. By employing almost all reported strategies, the students can manage their own learning without solely relying on teacher's supervision. As the result, students can be good, successful language learners.

The findings also showed that there are six reported strategies that are generally used by students in listening class. They are memory, cognitive, compensation, metacognitive, affective, and social strategies. From all these reported strategies, two or more strategies are applied in one task at hand. This circumstance possibly occurs since the learning strategies support each other if they are combined together (Huda, 1998, p. 57). Simply, it means that the more strategies are combined and used, the better results are achieved. Moreover, all students of non-English Department used the strategies in moderate level. It means that the strategies are not always used, yet it is still used quite often.

By applying learning strategies, the students are expected to be able to autonomously manage their own learning, so that can set their intention in achieving the learning purposes. Since this current study is focusing on listening, teacher's guidance is particularly necessary, even for students of higher education. However, it is better for the teacher to provide some chances and opportunities for students so they can freely decide what to learn during listening class. It is necessary for them not to merely rely on the single practice conducted in the classroom; instead, they have to be self-directed students to practice listening outside the class based on their own consideration. Thus, students are said as good or successful learners as long as they are aware of using and combining the appropriate learning strategies. Thus, they are comfortable to manage their learning. From this point of view, the students can improve their listening skill and their listening achievements.

Continuing the discussion, it is known that not every single action of specific strategies under useful strategies for listening is applied by students. For one general strategy, there are only one or two specific strategies that are intensively used. Following is the description of each strategy use ranked from the strategies that are used the most until the least. The first strategies mostly 
used by students are memory strategies. These strategies helped students cope with difficulties in remembering words or sentences that they just have listened to in order to complete the task. In this research, components of memory strategies that are mostly used by students are using imagery or imagine the word from the sound they heard, using keywords or familiar words that students know and considerate as similar words, and reviewing the known material they have learned in the previous meeting. This result is in accordance with the previous study that memory strategies have higher possibility to be applied in listening rather than other strategies (Huy, 2015, p. 29).

The second reported strategies that are used by students in listening are compensation strategies. Compensation strategies were employed by students in order to overcome their limitation. They did it by making intelligent guessing. Compensation strategies were mostly found when students were making their own understanding of words they heard. Compensation strategies are mostly used to compensate the lack of vocabulary and to make up the lack of grammatical knowledge (Oxford, 1990, p. 49).

Metacognitive strategies were the third strategies that are applied by students in listening. These strategies are mostly used by the students in form of paying a lot of attention to the recording and defining objectives in listening. It was done this way because they need to be aware of what they are listening to in order to accomplish the listening task. Metacognitive strategies are included in indirect strategies because these strategies are done not only during the recording was being played, instead, it lasted from pre-listening activities until whilst-listening activities. Since it is applied before the listening activities were practically done, students have enough time and various ways in applying these strategies (Jou, 2009, p. 6).

Cognitive strategies were the next reported strategies that are used by students in listening. Cognitive strategies were essential in learning a new language since they can be used to manipulate or transform the knowledge of a new language. In this research, components of cognitive strategies that are mostly used by students in listening are making the repetition of some words they heard, translating the words directly by assisted with the dictionary, and using pattern or language rules they were already known. Cognitive strategies allowed students to get more understanding of their learning. Moreover, in order to achieve top scores, students convey that they like watching English language movies or TV shows. By doing this, they can learn and practice the material in a fun way that they enjoy. Applying strategies in different ways are important since students may become self-regulators to manipulate the skill efficiently (Huang, 2009, p. 32). 
The next strategies that are reported in this study are affective strategies. Affective strategies are those that referring to students' emotions, attitudes, motivations, and values. In this research, it was revealed that students tried to control themselves to be focus and patient in order to succeed their listening. The obstacles in listening such as the quality of the recording, outside noise, personal thought on accomplishing the task, or difficult words and special terms of given material definitely influence students feelings and attitudes towards the activity. Thus, affective strategies play their roles during this situation (Ivarsson \& Palm, 2013, p. 17). Components of affective strategies that are mostly employed by students in this study were lowering their anxiety by having deep breathing or laughter and encouraging themselves by making a positive statement. Once the learning situation is controlled, students attempt to succeed their listening.

Social strategies are the last strategies employed by students in listening, and it is the strategies that are applied the least by students. Students conveyed that it is unusual for them to practice listening outside the classroom except for listening to music or watching movies. Besides, social strategies involve the existence of oral responses (two-way communication) that in the fact, classroom listening only tends to convey the meaning of spoken language without receiving any response. This reason is logical because intensive application of language requires supportive environment from where the language is used. This kind of environment may affect strategies accomplishment. In this case, classroom interaction offers only little opportunities for the use of social strategies with the exception of questioning for clarification (Ellis, 1994, p. 67). Furthermore, students are afraid of making mistake during the communication. That is why they tend to just listen without any intention to be involved in further activities (Huy, 2015, p. 29). In this study, components of social strategies that mostly employed by students are making clarification and verification by asking some questions related to the recording to make sure what they have heard is correct.

Aside from what strategies had been used by the students, how the strategies are applied so that it can enhance students' achievement also become a significant issue in language learning. This matter is related to the effectiveness of the strategies. Students' achievement can be used as one of the indicators that show the effectiveness of strategies use since they are significantly correlated (Amin, Aly, \& Amin, 2011, p. 10). Furthermore, Coskun (Coskun, 2010, p. 42) in his study implied that it is better for the teacher to include the strategy training in teaching-learning process to enhance students' competency. Simply, it can be said that from the students' listening scores, it can be seen how far the strategies influence their achievement. The finding from 
comparing students' average score of strategies use and an average score of listening task revealed that students with a good score of listening have a higher average score of strategies use. It means that the use of strategies is significant with the students' achievement. From this result, it can be inferred that the more often students use the learning strategies, the more effective result they can accomplish. As the result, students whose higher average score of strategies users have better listening score than their counterparts.

In this study, there are 18 students out of 30 students who got A mark in listening task, while 12 students got B mark. In term of the average score of strategies use, the score of the 18 students range from 2.9 to 3.3. Meanwhile, their counterpart's scores range from 2.3 to 2.8. This result showed that the use strategies in listening significantly support the students' achievement. This is also supported by another study that strategies are not the only determiner, yet it has a big influence in determining students' successful in learning the language (Bozorgian \& Pillay, 2013, p. 117).

It is inevitable that students' choice of using certain strategies is influenced by their goals to get the better listening achievement. Therefore, students' achievement is also influenced by their preference in using certain strategies in listening. The process of language strategies obviously exist and influence the language learning in which these strategies are consciously selected by the students. Thus, the score of students' listening task revealed that students are able to apply almost six components of learning strategies in listening, even though students' awareness and average use of the strategies are at the moderate level. This condition is actually acceptable since the students are non-English Department students, and they have never included in the field of strategies training to enhance students' consideration toward strategies use in listening.

As what had been mentioned before, referring to table 2, students' average scores in using strategies are range from 2.4 up to 3.1. In Oxford Classification, this classification is included in the range of moderate level or in other words, students only usually use the strategies (Oxford, 1990, p. 300). It means that students have not used the strategies as maximal as expected. Another possibility that comes to this situation is that students may have already applied the strategies. However, they were not aware enough of the application. They did not recognize that what they have done is categorized as strategies use. In this case, students are recognized as good strategies users when they are consciously using the strategies. It can be observed by making them stating what strategies they use, why they use those strategies, and how they use them in the learning process. 
Consulting the result of the questionnaire, the moderate use of the strategies implied that students still have subconscious awareness concerning the learning strategies use. However, this score is considerably quite high because it closely approaches the high level. It means that the students are actually quite aware, but they are not completely aware of their learning. Of course, this condition affects students' preference in using the strategies for their listening. It is revealed that students of non-English department still tend to apply the learning strategies in listening even though the focus of their study is not a language relating department. It is found that all of the strategies were employed, but it was applied in a different level of average use. Students are labeled as successful language learners when they can combine the strategies they use effectively (Cabaysa \& Baetiong, 2010, p. 24). By employing many kinds of learning strategies, the students can manage their learning on their own with less relying on the teacher supervision. As the result, they can be good, successful, and self-directed language learners. Indeed, successful learners tend to use a greater number of strategies and combine a number of strategies appropriately and effectively (Huda, 1998, p. 57).

Last but not least, the use of listening strategies has impacts to the listening achievement since they are in line with each other. In this case, however, not only what kind of strategies used in listening to that become the influential factor of students' listening achievement but the frequency of use or how often the students apply and accomplish the use of strategies also give impact to the students' listening achievements.

\section{CONCLUSION}

To sum up, it can be concluded that students of Governmental Science of the Muhammadiyah University of Ponorogo apply more than one strategy in listening, but memory strategies are the strategies mostly applied by the students. Both direct and indirect strategies are particularly applied. Moreover, compared to their listening achievement, the use of strategies is worthy. Despite its moderate use, the strategies are considerable to be used in listening class. Thus, this study encompassed how learning strategies are neglected in listening class for non-English Department students. However, the teacher should pay more attention to this concern so that listening activities designed for the students can suit students' way of learning. As the result, the use of learning strategies can be obtained better.

\section{REFERENCES}

Amin, I. A.-R., Aly, M. A.-S., \& Amin, M. M. (2011). A correlation study between EFL strategic listening and listening comprehension skills among secondary school students. Benha, Egypt: Benha University. 
Basir, A. (2014). Autistic students' learning strategies in writing English texts and their impacts on the teaching and learning process. Surakarta: Sebelas Maret University.

Bozorgian, H., \& Pillay, H. (2013). Enhancing foreign language learning through listening strategies delivered in L1: An experimental study. International Journal of Instruction, 6(1), 105-122.

Brown, H. D. (2006). Teaching by principles: An interactive approach to language pedagogy. New Jersey: Prentice Hall Regents.

Cabaysa, C. C., \& Baetiong, L. R. (2010). Language learning strategies of students at different levels of speaking proficiency. Education Quarterly, 61(8), 16-35.

Celce-Murcia, M. (2001). Teaching English as a second or foreign language. Boston: Heinle \& Heinle Publishers.

Chang, C. Y., Liu, S., \& Lee, Y. (2007). A study of language learning strategies used by college EFL learners in Taiwan. Language Learning, 3, 235-262.

Cohen, D. (1998). Strategies in learning and using a second language. London: Longman.

Coskun, A. (2010). The effect of metacognitive strategy training on the listening performance of beginner students. Novitas-ROYAL (Research on Youth and Language), 4(1), 35-50.

Ellis, R. (1994). The study of second language acquisition. New York: Oxford University Press.

Farlex. (2007). Retrieved January 20, 2016, from The Free Dictionary: http:/thefreedictionary.com

Gestanti, R. A. (2015). Students' learning strategies and their accomplishment in speaking English. Surakarta: Sebelas Maret University.

Ghaderpanahi, L. (2012). Using authentic aural materials to develop listening comprehension in the EFL classroom. English Language Teaching, 5(6), 146-153.

Gilakjani, A. P., \& M. R. (2011). A study of factors affecting EFL learners' English listening comprehension and the strategies for improvement. Journal of Language Teaching and Research, 2(5), 977-988. 
Gilakjani, A. P., \& Sabouri, N. B. (2016). Learners' listening comprehension difficulties in English language. English Language Teaching, 9(6), 123-133.

Harmer, J. (2007). How to teach English: New Edition. London: Pearson Education Limited.

Harmer, J. (2001). The practice of English language teaching. New York: Longman.

Huang, Y. F. (2009). The relationship between college students' learning strategies and their English speaking proficiency. Ming Chuan, : Ming Chuan Univ Press.

Huda, N. (1998). Relationship between speaking proficiency, reflectivityimpulsivity, and L2 learning strategies. Learners and Language Learning. RELC Anthology series, 39, 40-45. (W. Renandya, \& G. M. Jacobs, Eds.) Singapore: SEAMEO Regional Language Centre.

Huy, L. H. (2015). An investigation into listening strategies of EFL students. Asian Journal of Educational Research, 3 (4), 21-34.

Ivarsson, E., \& Palm, M. (2013). Listening strategies in the L2 classroom. Malmö högskola.

Jou, Y.-J. (2009). A study of english listening strategies applied by. Cheng Shiu: Cheng Shiu University.

Kassem, H. M. (2015). The relation between listening strategies used by egyptian EFL college sophomores and their listening comprehension and self-efficacy. English Language Teaching Journal, 8(2), 153-169.

Khamdani, A. K. (2014). Learning strategies applied by students of nursing academy in listening. Surakarta: Sebelas Maret University.

Liang, T. (2009). Language learning strategies- the theoretical framework and some suggestions for learner training practice. English Language Teaching Journa, 2(4), 199-206.

Milles, M. B., \& Huberman, A. M. (1984). Qualitative data analysis. A sourcebook of new methods. California: SAGE Publication, Inc.

Nation, I., \& Newton, J. (2009). Teaching ESL/EFL listening and speaking. New York: Routledge.

O'Malley, J. M. (1990). Learning Strategies in second language acquisition. Cambridge: Cambridge University Press. 
Oxford, R. L. (1990). Language learning strategies: What every teacher should know. Boston: Heinle \& Heinle Publishers .

Oxford, R. L. (2003). Language learning styles and strategies: An overview. London: GALA.

Penulis, T. (2015). Panduan Akademik 2015/2016. Ponorogo: UMP Press.

Razawi, N. A. (2011). Students' diverse learning styles in learning English as a second language. International Journal of Bussiness and Social Science, 2 (19), 179-186.

Richards, J. C. (2002). Methodology in language teaching. An anthology of current practice. New York: Cambridge University Press.

Rost, M. (1994). Introducing listening. London: Penguin Group.

Shi, C. (2011). A study of the relationship between cognitive styles and. Higher Education Studies, 1(1), 20-26.

Underwood, M. (1989). Teaching listening. London: Longman.

Ur, P. (1996). A course in language teaching practice and theory. Melbourne: Cambridge University Press.

Watthajarukiat, T. E. (2011). An investigation of English listening strategies used by Thai undergraduate students in public universities in the South Thailand. Journal of Art, 15(4), 1-17.

Weir, J. C. (1998). Communicative language testing. New Jersey: Prentice Hall Europe.

Wenden, A. \&. (1987). Learner strategies in language learning. New Jersey: Prentice Hall.

Zare, P. (2012). Language learning strategies among EFL/ESL learners: A review of the literature. International Journal of Humanities and Social Science, 2(5), 162-169.

Zhang, W.-S. (2007). Teach more strategies in EFL college listening classroom. US-China Education Review, 4(3), 71-76. 


\section{Author's Brief CV}

Rohfin Andria Gestanti is an English lecturer in Social and Political Science Faculty of the Muhammadiyah University of Ponorogo. She is currently teaching English for Specific Purposes (ESP) for Communication Science. Her field of interest is concerning the field of ESP material. 


\section{Appendix}

\section{Questionnaire of Learning Strategy in Listening English Text \\ Strategy Inventory for Language Learning (SILL) \\ Version 7.0 (ESL/EFL) @ R. Oxford, 1990}

\section{Main Questionnaire}

Please read each statement and mark the response $(1,2,3,4,5)$ that tells how true of you the statement is

1. Never or rarely

2. Less than half of the time

3. About half of the time

4. More than half of the time

5. Almost always

\begin{tabular}{|c|c|c|c|c|c|c|}
\hline \multirow{2}{*}{ No } & \multirow[t]{2}{*}{ Item } & \multicolumn{5}{|c|}{ Response } \\
\hline & & & & & & \\
\hline 1 & $\begin{array}{l}\text { I think of relationship between what I already know and new } \\
\text { things I learn in English }\end{array}$ & 1 & 2 & 3 & 4 & 5 \\
\hline 2 & $\begin{array}{l}\text { I use new English word in a sentence so I can remember } \\
\text { them }\end{array}$ & 1 & 2 & 3 & 4 & 5 \\
\hline 3 & $\begin{array}{l}\text { I connect the sound of a new English word and an image or } \\
\text { picture of the word to help me remember the word }\end{array}$ & 1 & 2 & 3 & 4 & 5 \\
\hline 4 & $\begin{array}{l}\text { I remember a new English word by making a mental picture } \\
\text { of a situation in which the word might be used }\end{array}$ & 1 & 2 & 3 & 4 & 5 \\
\hline 5 & I review English lesson often & 1 & 2 & 3 & 4 & 5 \\
\hline \multirow[t]{2}{*}{6} & $\begin{array}{l}\text { I remember the new English words or phrases by } \\
\text { remembering their location on the page, on the board, or on a } \\
\text { street sign }\end{array}$ & 1 & 2 & 3 & 4 & 5 \\
\hline & PART B & & & & & \\
\hline 7 & f English & 1 & 2 & 3 & 4 & 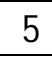 \\
\hline 8 & I use the English words I know in different ways & 1 & 2 & 3 & 4 & - \\
\hline 9 & $\begin{array}{l}\text { I watch English language TV shows spoken in English or go } \\
\text { to the movies spoken in English }\end{array}$ & 1 & 2 & 3 & 4 & 5 \\
\hline 10 & $\begin{array}{l}\text { I look for words in my own language that are similar to new } \\
\text { words in English }\end{array}$ & 1 & 2 & 3 & 4 & 5 \\
\hline 11 & I try to find pattern in English & 1 & 2 & 3 & 4 & 5 \\
\hline 12 & $\begin{array}{l}\text { I find the meaning of an English word by dividing it into } \\
\text { parts that I understand }\end{array}$ & 1 & 2 & 3 & 4 & 5 \\
\hline 13 & I try not to translate word-for-word & 1 & 2 & 3 & 4 & 5 \\
\hline 14 & $\begin{array}{l}\text { I make summaries of information that I hear or read in } \\
\text { English }\end{array}$ & 1 & 2 & 3 & 4 & 5 \\
\hline
\end{tabular}

Journal on English as a Foreign Language, 7(1), 35-58

Copyright (C) 2017 by JEFL, p-ISSN 2088-1657; e-ISSN 2502-6615 


\begin{tabular}{|c|c|c|c|c|c|c|}
\hline & PART C & & & & & \\
\hline 15 & To understand unfamiliar English words, I make guesses & 1 & 2 & 3 & 4 & 5 \\
\hline 16 & $\begin{array}{l}\text { I make up new words if I do not know the right ones in } \\
\text { English }\end{array}$ & 1 & 2 & 3 & 4 & 5 \\
\hline 17 & I try to guess what the other person will say next in English & 1 & 2 & 3 & 4 & 5 \\
\hline \multirow[t]{2}{*}{18} & $\begin{array}{l}\text { If I can't think of an English word, I use a word or phrase that } \\
\text { means the same thing }\end{array}$ & 1 & 2 & 3 & 4 & 5 \\
\hline & PART D & & & & & \\
\hline 19 & I try to find as many ways as I can to use my English & 1 & 2 & 3 & 4 & 5 \\
\hline 20 & $\begin{array}{l}\text { I notice my English mistakes and use that information to help } \\
\text { me do better }\end{array}$ & 1 & 2 & 3 & 4 & 5 \\
\hline 21 & I pay attention when someone is speaking English & 1 & 2 & 3 & 4 & 5 \\
\hline 22 & I try to find out how to be a better learner of English & 1 & 2 & 3 & 4 & 5 \\
\hline 23 & $\begin{array}{l}\text { I plan my schedule so I will have enough time to study } \\
\text { English }\end{array}$ & 1 & 2 & 3 & 4 & 5 \\
\hline 24 & $\begin{array}{l}\text { I look for opportunities to listen as much as possible in } \\
\text { English }\end{array}$ & 1 & 2 & 3 & 4 & 5 \\
\hline 25 & I have clear goals for improving my listening skill & 1 & 2 & 3 & 4 & 5 \\
\hline \multirow[t]{2}{*}{26} & I think about my progress listening English & 1 & 2 & 3 & 4 & 5 \\
\hline & PART E & & & & & \\
\hline 27 & (1) & 1 & 2 & 3 & 4 & 5 \\
\hline 28 & $\begin{array}{l}\text { I encourage myself to listen to English text even when I am } \\
\text { afraid of making mistake }\end{array}$ & 1 & 2 & 3 & 4 & 5 \\
\hline 29 & I give myself a reward or treat when I do well in English & 1 & 2 & 3 & 4 & 5 \\
\hline 30 & $\begin{array}{l}\text { I notice if I am tense or nervous when I am studying or using } \\
\text { English }\end{array}$ & 1 & 2 & 3 & 4 & 5 \\
\hline 31 & I write down my feelings in a language learning diary & 1 & 2 & 3 & 4 & 5 \\
\hline \multirow[t]{2}{*}{32} & $\begin{array}{l}\text { I talk to someone else about how I feel when I am learning } \\
\text { English }\end{array}$ & 1 & 2 & 3 & 4 & 5 \\
\hline & PART F & & & & & \\
\hline 33 & $\begin{array}{l}\text { If I do not understand something in English, I ask the other } \\
\text { person to slow down or say it again }\end{array}$ & 1 & 2 & 3 & 4 & 5 \\
\hline 34 & I ask English speaker to correct me when I talk & 1 & 2 & 3 & 4 & 5 \\
\hline 35 & I practice English with other students & 1 & 2 & 3 & 4 & 5 \\
\hline 36 & I try to learn about the culture of English speakers & 1 & 2 & 3 & 4 & 5 \\
\hline
\end{tabular}


